\title{
The Militarization of Law Enforcement: Evidence from Latin America
}

\author{
Gustavo A. Flores-Macías and Jessica Zarkin
}

\begin{abstract}
What are the political consequences of militarizing law enforcement? Across the world, law enforcement has become increasingly militarized over the last three decades, with civilian police operating more like armed forces and soldiers replacing civilian police in law enforcement tasks. Scholarly, policy, and journalistic attention has mostly focused on the first type, but has neglected the study of three main areas toward which we seek to contribute: 1) the constabularization of the military-i.e., when the armed forces take on the responsibilities of civilian law enforcement agencies, 2) the extent to which this process has taken place outside of the United States, and 3) its political consequences. Toward this end, we unpack the concept of militarized law enforcement, develop theoretical expectations about its political consequences, take stock of militarization in Latin America, and evaluate whether expectations have played out in the region. We show that the distinction between civilian and military law enforcement typical of democratic regimes has been severely blurred in the region. Further, we argue that the constabularization of the military has had important consequences for the quality of democracy in the region by undermining citizen security, human rights, police reform, and the legal order.
\end{abstract}

S ights of soldiers patrolling urban neighborhoods, responding to reported crimes in progress, collecting evidence, and staffing checkpoints on major highways are increasingly common worldwide. Latin America, now the most violent region in the world, is no exception in the trend to militarize law enforcement. In Mexico, for example, more than 67,000 troops have participated in widespread policing operations since 2006 (Ordorica 2011). In Brazil, the armed forces have helped state governments regain control of urban areas, with soldiers patrolling city streets on nearly 100 days in 2016 (The Economist 2017). In Honduras, the government created the Military Police for Public Order (PMOP) in 2013 to combat drug trafficking and close to 6,000 soldiers take part in joint army-police operations (Secretaría de Defensa Nacional de Honduras 2013). Even countries that historically have lacked a military, like Costa Rica and Panama, are considering proposals to militarize law enforcement.

*Data replication sets are available in Harvard Dataverse at: https://doi.org/10.7910/DVN/W1YYEV

\section{A list of permanent links to Supplemental Materials provided by the authors precedes the References section.}

(D) Gustavo A. Flores-Macias is Associate Professor of Government and Associate Vice Provost for International Affairs at Cornell University (gaf44@cornell.edu). He is the author of After Neoliberalism? The Left and Economic Reforms in Latin America (Oxford University Press, 2012), which received the Latin American Studies Association's Tomassini Book Award, and the editor of The Political Economy of Taxation in Latin America (Cambridge University Press, 2019).

Jessica Zarkin is a Doctoral Candidate in the Government Department at Cornell University (jz684@cornell.edu). Her research focuses on the linkages between state institutions and citizens, with a special interest in security, policing, and policecommunity partnerships. Her research has been funded by the Andrew Kohut Fellowship Program at the Roper Center for Public Opinion Research and the Houston I. Flournoy Graduate Fellowship.

We received helpful feedback from presentations at Barnard, Cornell, and Syracuse University, as well as the Latin American Studies Association's 2018 annual meeting and the 2019 Politics of Policing Virtual Conference. We are especially grateful to John Bailey, Matthew Cleary, Matthew Ingram, Ned Littlefield, Eduardo Moncada, Sarah Kreps, Eduardo Clark, José Sánchez, Christopher Sabatini, Hillel Soifer, Christopher Sullivan, Richard and Maritza Williamson, and anonymous reviewers for their comments. 
The involvement of the region's militaries in domestic security might have been common during military dictatorships, but it had been unusual in democratic regimes. While military regimes relied on their own cadre for internal policing or incorporated the police into the military's repressive apparatus, as in Argentina, Chile, or Uruguay (Pereira 2005), contemporary democracies tend to have a separation between the roles of police (public safety) and military (national security) - a central element in civil-military relations conducive to civilian control over the military (Dammert and Bailey 2005). As the evidence we present suggests, this distinction is increasingly less meaningful in Latin American democracies, where governments have militarized public safety and recast the role of the armed forces for domestic law enforcement purposes.

Despite the prevalence of militarized law enforcement, scholarly, policy, and journalistic attention has mostly focused on a fairly narrow form of militarizationnamely when the police take on similarities to militaries - with a fairly narrow geographic range: the United States. Existing research has focused on the prevalence of SWAT teams with military-grade weapons in police departments across the United States (Balko 2013; Kraska 2007), whether they have strained police-community relations (American Civil Liberties Union 2014) or had an effect on levels of violence (Delehanty et al. 2017).

While this research constitutes an important first step, it has neglected the prevalence and consequences of other forms of militarization taking place outside of the U.S. With that oversight in mind, we break ground by making five main contributions: 1) unpacking the concept of militarization of law enforcement to accommodate different forms; 2) developing theoretical expectations regarding its consequences in democratic contexts, 3) taking stock of the extent of militarization in Latin America, 4) evaluating whether theoretical expectations about its consequences have played out in the region, and 5) discussing the implications of obviating the lines between national security and public safety-what Tilly (1992) characterized as external versus internal coercion. We argue that the distinction between civilian and military law enforcement typical of democratic regimes has been blurred in Latin America. We also show that the constabularization of militaries ${ }^{1}$ has had important consequences in the region for citizen security, police reform, the legal order, and the quality of democracy more generally.

\section{Scholarship on the Militarization of Law Enforcement}

Inspired by scholarship from Huntington (1957) and others on military organization and professionalization, toward the end of the 1970s the literature on civil-military relations in Latin America focused on the causes and consequences of military coups, as well as regime dynamics under bureaucratic-authoritarian rule (Fitch 1998; Hunter 1997; Norden 1996; Remmer 1989; Stepan 1988). During the third wave of democracy, scholars continued to study civil-military relations with an eye towards the challenges of democratic consolidation and emphasizing civilian control over the military, coup proofing, and the armed forces' role in regional security (e.g., Arceneaux 2001; Jaskoski 2013; Pérez 2015b; Pion-Berlin and Trinkunas 2010; Rittinger and Cleary 2013). ${ }^{2}$ In parallel, new scholarship emerged on the change in paradigm from national to citizen security, as well as the types and obstacles to police reform (Dammert and Bailey 2005; Frühling 2003; González 2017; Hinton 2006; Moncada 2009; Ungar 2011).

Despite the vast and rich literature on the military and police in Latin America, academic scholarship has remained relatively silent on the role of the armed forces in domestic security and on the blurring of the line between militaries and police forces under democratic regimes. Instead, recent literature on militarization of law enforcement has mostly adopted a U.S.-centric approach. Most of it corresponds to journalistic accounts drawing attention to the nationwide trend of militarization of local police departments, but several academic studies have documented the adoption of military equipment and tactics by civilian police under the Department of Defense's 1033 Program (Balko 2013; Kraska 2007).

Some authors have equated militarization of police in the United States with better training, discipline, and accountability (Wood 2015). A strand of research (den Heyer 2013) even characterizes the militarization of police as part of a "natural progression in the evolution and professionalization of . . . policing" (p. 347). Others are less sanguine about the consequences of militarizing the police, finding that the 1033 Program contributes to a higher number of fatalities from officer-involved shootings (Delehanty et al. 2017), undermines policecommunity relations (Bickel 2013), and fails to enhance officer safety or reduce local crime (Mummolo 2018).

To the extent that the "police-icizing" or constabularization of the military has been studied, it has been in the limited contexts of U.S. military interventions in Afghanistan and Iraq (Kraska 2007) or indirectly as a byproduct of U.S. anti-drug policies during peacetime (Youngers 2000). Whereas existing research has mostly focused on the financial and training assistance that the U.S. military has provided abroad (Youngers 2004; Isacson and Kinosian 2017) or on rich, country-specific descriptions (Moloeznik and Suárez 2012; Zaverucha 2008), the systematic study of the consequences of the most extreme form of militarization-constabularized soldiers-remains scarce. Notable exceptions include Pion-Berlin's research (2017) on differences in military missions in Mexico and Arana and Ramírez's (2018) and Trujillo Álvarez's (2018) studies on re-militarization in Central America. 
Although existing scholarship provides a valuable point of departure, we move forward this relatively underdeveloped research agenda by: 1) defining and developing the concept and types of militarized law enforcement; 2) drawing theoretical expectations for the consequences of militarizing public safety for the quality of democracy regarding citizen security, human rights, police reform, and the legal order; 3) taking stock of militarization in Latin America; and 4) assessing whether theoretical expectations have played out in the region, with an emphasis on the highest degree of militarization: constabularization.

\section{Conceptualizing the Militarization of Law Enforcement}

Kraska $(2007,3)$ defines militarization of police as "the process whereby civilian police increasingly draw from, and pattern themselves around, the tenets of militarism and the military model." While this definition might reflect the U.S. experience, it does not account for the experience beyond its southern border, where the armed forces themselves conduct law enforcement tasks previously reserved for civilian police.

To address this, we go up Sartori's (1970) ladder of abstraction by introducing the concept of "militarized law enforcement," which can in turn comfortably accommodate different sub-types beyond civilian police. We define militarized law enforcement as the process through which government agencies tasked with providing public safety adopt the weapons, organizational structure, and training typical of the armed forces. This broader definition includes not only civilian police that pattern themselves like militaries (as Kraska's definition implies), but also paramilitary forces and constabularized soldiers providing domestic public safety.

The different types of militarized law enforcement form a continuum in practice (refer to figure 1). On the non-militarized end of the spectrum, civilian police report to a civilian authority and are under the jurisdiction of civilian law. They are trained to use force as a last resort, follow a serve-and-protect directive, tend to be organized in low hierarchy structures, and often focus on community-oriented policing.

The second type is militarized police, which share some features of their non-militarized counterparts, such as the civilian jurisdiction and low-hierarchy structure, but also rely on some military-grade weapons and gear, military-style formations, and tactics. Examples include the proliferating SWAT teams in local law enforcement in the United States and immediate-reaction units in national and local police forces in Latin America.

The next type moving toward the most-militarized end is the paramilitary police. Though one cannot find a standard gendarmerie-style force, paramilitary forces more organically incorporate practices typical of the armed forces. Although they preserve the non-lethal use of force as their main modus operandi, maintain a serveand-protect mentality, and are in most cases under the jurisdiction of civilian law, they rely on military weapons and gear, have a more hierarchical structure, operate based on military deployment tactics and units, and some might even report to the Ministry of Defense. Examples

\section{Figure 1}

\section{Law enforcement types based on degree of militarization}

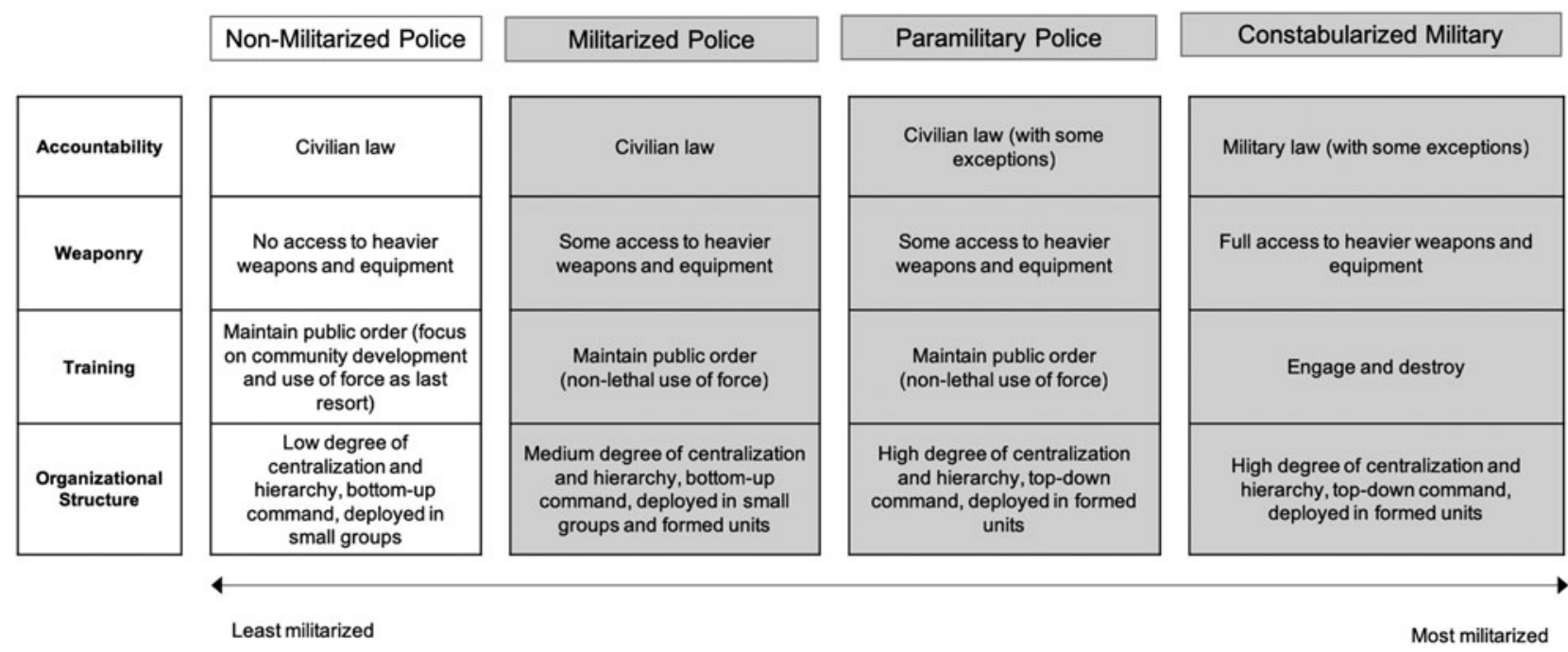


include Chile's Carabineros, Brazil's Polícia Militar, Spain's Guardia Civil, and France's Gendarmerie Nationale.

In the most extreme form of militarization of law enforcement, the armed forces take on public safety tasks themselves, including crime prevention (security patrols); crime fighting (drug crop eradication and interdiction, drug and arms seizures, searches and arrests, evidence gathering and interrogation); and prison security. Constabularized militaries report to the Ministry of Defense, operate under military law, follow a strict hierarchical structure, have full access to the most destructive weapons, and are trained according to an engage-anddestroy directive. Examples of constabularized militaries are the Peruvian armed forces during part of Alberto Fujimori's rule, and the semi-permanent crime-fighting operations across the national territory by Honduran and Mexican armed forces, among others.

Given that there is no single model for any of the four different types, there may be differences across countries. For example, paramilitary police may be under the Ministry of Defense in some countries but a Ministry of Public Safety or the Interior in others. Additionally, seldom do countries rely on a single type of law enforcement. Rather, depending on the legal framework, multiple types can operate simultaneously (e.g., nonmilitarized municipal police and militarized state police).

\section{Regional Drivers of Militarization}

The militarization of law enforcement in the region has mainly responded to rising levels and violent nature of crime, the appeal of punitive populism amid perceptions of police incompetence and corruption, and incentives created by U.S. foreign policy. ${ }^{3}$ First, with 2.6 million homicides between 2000 and 2016 (Marinho and Tinoco 2017), Latin America is today the most unsafe area in the world outside of a war zone. The deterioration of public safety has been precipitous in places such as El Salvador, Mexico, and Venezuela, where homicide rates doubled or tripled in short periods of time. Not surprisingly, addressing crime has become the number one public concern in most countries in the region (Latinobarómetro 2015).

Organized crime's levels of sophistication, brutality, and resources have prompted governments to militarize public safety. Criminal organizations in Latin America increasingly rely on weapons typically reserved for militaries, as well as on cutting-edge technology for communication and transportation. The cross-border nature of their operations and their seemingly unlimited resources to bribe officials have changed considerably the tactical power of criminal organizations vis-à-vis civilian law enforcement, which are often poorly paid, trained, and equipped.

Second, punitive populism-when leaders appeal to tough-on-crime approaches for electoral gain-has been fueled by perceptions of incompetence and corruption of civilian police agencies. Compared to the police, militaries are often perceived as more competent, less prone to corruption, and more inclined to put the interests of the country first. The armed forces enjoy greater trust than the police in all but two countries-Chile and Uruguaywhere support is roughly the same (Americas Barometer by the Latin American Public Opinion Project (LAPOP) 2014).

These perceptions have become political incentives that lead to punitive populism, which has increased the role of the armed forces in domestic security. Rather than investing in the more difficult task of strengthening civilian law enforcement institutions - a protracted process often requiring legislative negotiations - an electorally flashy and easily accessible alternative for executives has been to rely on the armed forces. By tapping into fear of crime, such actions have broad cross-class appeal regardless of their effectiveness.

Third, U.S. anti-drug policy abroad has contributed to the constabularization of the military in Latin America. Although the U.S. military is generally barred from participating in domestic law enforcement activities, ${ }^{4}$ it has been fairly active in the region (Weeks 2006). Military assistance has taken the form of funding toward weapons, equipment, training, construction of military bases, and monitoring and interdiction of drug trafficking. In total, between 2000 and 2016 the U.S. Department of Defense provided Latin American and the Caribbean over US\$5.5 billion in security aid (Security Assistance Monitor 2017). This aid is often tied to military equipment-such as Blackhawk and Apache helicopters - provided as in-kind assistance for anti-drug efforts. The number of special operations forces training missions to Latin America tripled between 2007 and 2014, and the U.S. currently works with the security forces of all countries in Latin America except Cuba, Venezuela, and Bolivia (Isacson and Kinosian 2017). Overall, the assistance toward the armed forces' drug eradication and seizures far exceeds the money invested in helping states strengthen civilian institutions (Isacson and Kinosian 2017).

\section{Theorizing the Consequences of Constabularization}

Having unpacked the different types of militarization of law enforcement and discussed its drivers in the region, we turn to developing theoretical expectations about political consequences. In particular, we expect differences along four dimensions-accountability, weaponry, training, and organizational structure - to have important consequences for key features of democratic governance: citizen security, human rights, police reform, and the legal order. $^{5}$ Although we expect their consequences to intensify and become more prevalent as the degree of militarization increases, we give special consideration to the consequences of the most extreme type: constabularized militaries. 
First, the heavy weaponry, combat training, and tactical organization and deployment that come with militarization will translate into greater disruptive capacity. Since these features of militarization are meant to maximize destructive power, militarized personnel will be more likely than non-militarized counterparts to use excessive force. For example, levels of violence will increase as the type of law enforcement moves away from traditional service weapons-such as Glock pistols —and closer to military weapons — such as submachine guns and assault rifles. Combat training meant to eliminate enemies rather than arrest suspects will also result in greater violence. The centralized, hierarchical organization characteristic of militaries will make personnel all the more effective at maximizing disruption. These features of militarized units, which generate greater destructive capacity, will result in larger numbers of casualties and wounded as the degree of militarization increases.

In the case of constabularized militaries, the combination of military weapons, training based on an engageand-destroy mentality, and a centralized, hierarchical organization will result in the greatest disruptive capacity conducive to intensifying violence. As Lawson $(2018,1)$ notes, security personnel enjoy a lot of discretion in "deciding how to handle the situations they encounter." Given their highly hierarchical structure and centralized management and decision making, involving the armed forces in law enforcement increases the distance (both social and physical) between communities and security personnel, which makes the military more likely to use force compared to civilian law enforcement counterparts that are embedded in the communities (Lawson 2018).

Further, not only will more destructive weapons, training, and organization lead to more wounded and deaths in discretionary contexts, but they will also escalate violence by creating incentives for organized crime to fight back and respond in kind (Lessing 2017; Osorio 2015). Because militarized features result in a greater disruptive capacity, constabularized militaries' actions will encourage the greatest backlash from organized crimea rational survival strategy that results in tit for tat escalation, as Lessing $(2013$, 2017) has shown in Brazil, Colombia, and Mexico. Holding the will to enforce the law constant, militaries' greater disruptive capacity compared to police will elicit a more violent reaction from organized crime.

Second, in the high-risk, highly-discretionary contexts typical of law enforcement, the greater disruptive power that comes with greater militarization will be conducive to more human rights violations-including warrant-less searches, illegal detentions, torture, and extra-judicial killings. Whereas non-militarized police are trained with an emphasis on developing relations with the community, de-escalating conflict, and exercising restraint on the use of force, constitutional protections will be more difficult to uphold as law enforcement personnel move away from this directive and closer to overwhelming and eliminating an enemy (Dunlap 1999).

In the most extreme form of militarization-constabularization-military-style training and capacity will make security personnel more prone to treating suspected criminals as a threat to their survival and reacting violently - even in situations that do not require the lethal use of force (Dunn 2001). The centralized, hierarchical organizational structure typical of the military leaves more room for abuse because of the physical and psychological distance they generate vis-à-vis citizens (Willits and Nowacki 2014). This does not mean that non-militarized personnel are always respectful of human rights, but that the armed forces' greater disruptive capacity will result in a comparatively higher prevalence of human-rights abuses.

Third, reforming the less militarized agencies will become harder as the type of law enforcement moves away from non-militarized police and toward constabularization. Because of their popularity among the public and political expediency, ${ }^{6}$ more militarized forms of law enforcement reduce incentives for police reform. Widespread support for tough-on-crime policies increase electoral incentives to further militarization while reducing incentives for channeling necessary resources toward reforming the police (González 2017; Moncada 2009, 432).

In the case of constabularization, the military's greater disruptive capacity conveys the impression of competence at providing public safety (Bitencourt 2007; Flores-Macías and Zarkin 2019). Because of constabularization's popularity, leaders withdrawing the armed forces from the streets come across as soft on crime and risk paying an electoral penalty. Conversely, institution-building of civilian law enforcement agencies does not lend itself to quick public relations gains. Instead, police reform tends to be slow-moving and technically difficult, and requires sustained political commitment, cooperation across party lines, and between national and local authorities. Because of these political incentives and the low hurdles executives face for deploying the military, governments will tend to allocate resources toward military budgets to strengthen domestic public safety, even if non-militarized law enforcement are in desperate need of reform. In short, although constabularization is in part a consequence of ineffective and unreformed police, once adopted, constabularization in turn reduces the incentives for police reform.

Fourth, as the type of law enforcement moves away from civilian legal jurisdictions and becomes subject to military law, the legal framework will less-comfortably accommodate the armed forces' domestic policing in a democracy (Amnesty International 2017; Dunlap 
Figure 2

Theoretical expectations for increased militarization

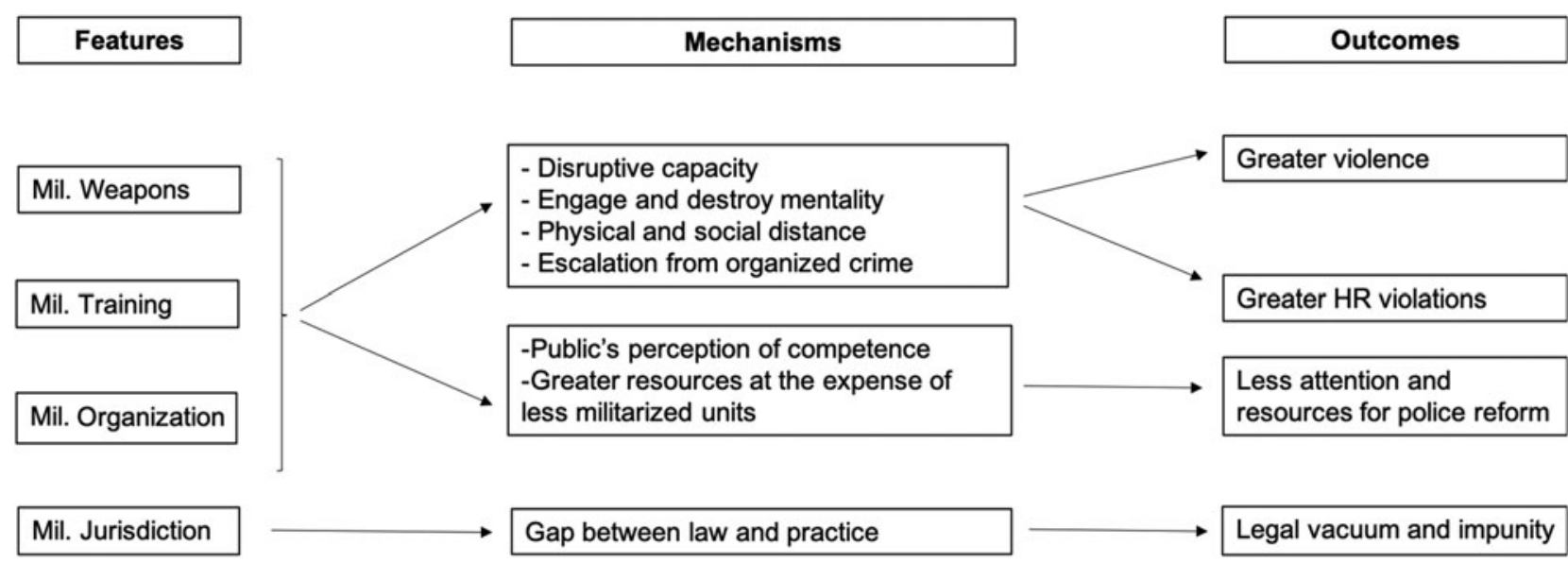

1999). In the absence of laws that regulate the military's domestic law enforcement tasks, militaries in some countries will operate without clearly defined legal boundaries. This can undermine the rule of law and contribute to a sense of impunity whenever the armed forces engage in violations of constitutional protections. While constabularization within the scope of the law provides greater legal certainty to the armed forces' domestic actions, rarely is the domestic conduct of soldiers as fully and clearly regulated as police action in democratic contexts, especially those with weak institutional settings as in Latin America.

In short, as shown in figure 2, we expect higher levels of violence, greater human rights violations, more difficulty in reforming non-militarized police, and a greater disconnect between law enforcement and the legal framework as the degree of militarization increases. Constabularized soldiers will be more likely to elicit these outcomes than paramilitary police, and they will in turn be more likely among paramilitary police than lessmilitarized counterparts. Even when units with different degrees of militarization are deployed jointly-e.g., soldiers alongside federal police-we can expect these differences to play out, since their disruptive capacities are different, as are the legal frameworks that regulate their conduct.

\section{Taking Stock of the Militarization of Law Enforcement}

We now turn to evaluating these hypotheses about the consequences of militarization based on evidence from Latin America. The first step is to determine the extent to which the phenomenon has taken place in the region, excluding cases of counterinsurgency because historically this has been a task generally reserved for the armed forces. We classify countries based on the highest level of militarization of law enforcement operating within its territory, although in most cases several law enforcement types co-exist (figure 3). For the extreme case of constabularization of the military, we make a distinction between cases of limited constabularization-countries where militaries have performed law enforcement functions in narrow geographic areas for short periods of time -and generalized constabularization-where the armed forces have carried out those functions in a sustained fashion across the national territory. To our knowledge, this is the first systematic effort to take stock of militarization in Latin America.

\section{Non-Militarized Police}

Although examples of non-militarized police remain in the region at the subnational level, as is the case in local or municipal law enforcement, at the national level there is no country that relies exclusively on this type of police. In all countries, national police rely on tactical units with military training, as well as assault weapons, Humvees, and other military gear for their routine daily operations. Even in Costa Rica, where the 1949 Constitution abolished the armed forces, units with military training exist since at least 1983, especially within the Dirección de Inteligencia y Seguridad, which reports directly to the president (González 2008).

\section{Militarized Police}

Only two countries in the region rely exclusively on militarized civilian police: Costa Rica and Panama, neither of which has a military. Having abolished its army in 1948, Costa Rica relies on its civilian Fuerza 


\section{Figure 3}

Highest degree of militarized law enforcement by country

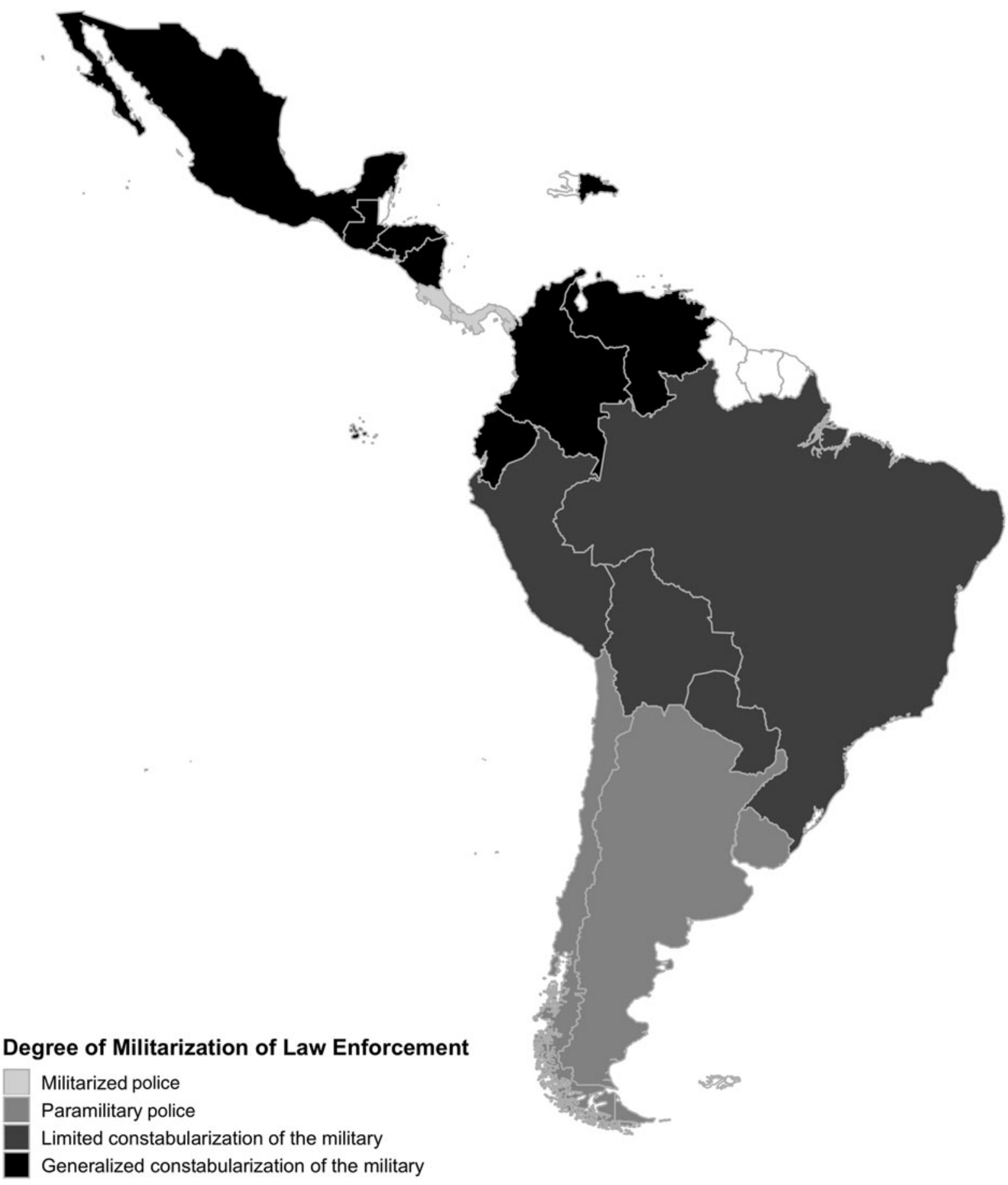

Note: Generated by the authors. See appendix for sources.

Pública for law enforcement purposes, including crime prevention and investigation, arrests, border control, and prison management. In Panama, the civilian $\mathrm{Na}-$ tional Police has carried out these functions since the 1989 U.S. military intervention. Additionally, special operation forces like the Antinarcotics Special Forces (FEAN) in Panama and the Unidad Especial de Intervención and Fuerza Especial Operativa in Costa Rica are militarized police units in charge of maintaining public order. 


\section{Paramilitary Police}

Argentina, ${ }^{7}$ Chile, and Uruguay primarily rely on paramilitary style police forces and have generally refrained from engaging the military in policing activities. In Argentina, the main law enforcement forces are the Federal Police, the Airport Security Police, and the Provincial Police, as well as two paramilitary forces: the National Gendarmerie and the Naval Prefecture. Although the military has provided logistical and technological assistance under joint operations near the borders such as the Operativo Combinado Abierto Misiones (De Vedia 2016), these civilian police and paramilitary agencies remain in charge of crime-fighting activities such as drug and arms seizures and surveillance (Telam 2017). In Chile, the Carabineros are the paramilitary force legally tasked with the country's internal law enforcement, including crime prevention, crime fighting, and prison security. Although they had been under civilian control on and off throughout the twentieth century, they remain under civilian control in the Ministry of the Interior since 2011. In Uruguay, president José Mujica (2010-2015) combined existing forces-including the anti-riot police (Guardia de Granaderos) and the SWAT team (Grupo Especial de Operaciones) - in 2010 to create the paramilitary police Regimiento Guardia Nacional Republicana (Porfilio 2015). This gendarmerie-style force is engaged in crime prevention, crime fighting, and prison security (El Pais 2016).

\section{Limited Constabularization of the Military}

Four countries in the region involve their militaries in geographically limited law enforcement operations: Bolivia, Brazil, Paraguay, and Peru. While their governments rely on the armed forces to address drug trafficking and organized crime, military operations tend to be restricted geographically and temporally. In Paraguay, the National Police have generally led efforts to address organized crime, including drug interdiction and drug crop eradication since president Andrés Rodríguez created the National Anti-Drug Secretariat (SENAD) in 1992 (U.S. Department of State 2015). However, beginning with Fernando Lugo's administration (2008-2012), governments have at times assigned the armed forces to domestic law enforcement. In particular, the military's Fuerzas Especiales have participated in SENAD's anti-drug activities, especially in the areas of Amambay, Concepción, and San Pedro, during the presidency of Horacio Cartes (2013-2018). ${ }^{8}$

In Peru, the armed forces have been involved intermittently in domestic law enforcement since Alberto Fujimori's authoritarian rule, especially in areas where Shining Path has been thought to operate. Since 2003, governments have declared the Valley of the Apurímac, Ene, and Mantaro Rivers (the VRAEM region in Spanish), where $70 \%$ of Peru's cocaine is produced, as emergency zones and given the armed forces control over the internal security of the region (Jaskoski 2013). In 2016 and 2017 president Pedro Pablo Kuczynski renewed the states of emergency in the several districts of Huancavelica, Ayacucho, and Cuzco (La Razón 2016) and VRAEM region (El Peruano 2016; Perú21 2017) to deploy the armed forces against drug trafficking.

In Bolivia, the armed forces have participated in domestic law enforcement in three broad areas: maintaining internal political order, fighting drug trafficking, and providing citizen security. President Evo Morales (2006-present) temporarily increased the military's involvement: on and off since 2009, more than 2,000 members of the armed forces have participated in joint military-police patrols and arrests under Plan Ciudad Segura in cities like La Paz, El Alto, Cochabamba, and Santa Cruz (Ministerio de Defensa de Bolivia 2012). In addition to participating in urban policing, the armed forces have been involved in efforts against contraband activity and drug crop eradication operations in the Cochabamba tropics, los Yungas, and the national parks.

In Brazil, every president has deployed the military to address violence in Rio de Janeiro since the federal government sought to regain control of 20 to 30 favelas in Operation Rio (November 1994-January 1995) (Donadio 2016). ${ }^{9}$ Recent interventions include the participation of up to 40,000 members of the national army in border security (Agatha Operations) starting in 2011, the temporary occupation of Rio's favelas in 2014-2015 (Garantia da Lei e da Ordem missions), and the control of public demonstrations, strikes, and prison riots-including president Michel Temer's (2016-2018) deployment of troops to the streets of Brasilia to quell protests against him in May 2017 and authorization for the army to take control of public security in Rio de Janeiro in February 2018.

\section{Generalized Constabularization of the Military}

In nine countries the armed forces are involved in sustained law-enforcement tasks across the national territory. Excluding counter-insurgency operations, in Colombia the armed forces have been involved in internal order since the 1960s (Leal Buitrago 2004). In 1998, Andrés Pastrana (1998-2002) created the First Battalion Against Drug-Trafficking, later institutionalized as the Army's Counternarcotic Brigade, which led aerial and manual eradication operations, drug seizures, and the destruction of laboratories. By the time Plan Colombia was adopted in 1999, the number of domestic military operations to address drug trafficking reached 977 in 2005 (Schultze-Kraft 2012). In 2011, the Fourteenth Directive from the Ministry of National Defense involved the military in the fight against organized crime (known as BACRIM), through joint operations with the National Police (Llorente and McDermott 2014). For example, 
Operation Troy involved 1,000 members of the National Police and 3,000 soldiers in the Caucasia area (McDermott 2011). Despite the 2016 peace accord with the FARC, the government continues to employ the military in fighting drug trafficking and contraband. Currently 300,000 members of the armed forces work in citizen security activities throughout the country, of which 60,000 have been deployed under Plan Victoria to occupy the former FARC zones of influence (160 municipalities) (Noticias de América Latina y el Caribe 2017).

In the Dominican Republic, the armed forces have participated in repeated operations in urban areas and in joint army-police operations that include security checkpoints, patrolling, and vehicle searches since 2001. In 2013 the Federal Government launched the Plan of Internal and Citizen Security Operations led by the recently created Comando Conjunto Unificado (Donadio 2014). Since then, 2,000 soldiers have participated in joint army-police patrols in several of the country's main cities, including La Altagracia, San Cristóbal, Santiago de los Caballeros, and Santo Domingo (Paniagua 2017).

In Ecuador the armed forces' involvement in domestic law enforcement went from sporadic to semi-permanent. During the late 1990s and early 2000s, Ecuadorian presidents Jamil Mahuad, Gustavo Noboa, and Alfredo Palacio signed executive decrees that allowed the armed forces to temporarily take over security measures in several provinces, including the city of Quito. In 2010 president Rafael Correa (2007-2017) increased the number of operations and tasks involving the armed forces. Under his 2011 Plan Nacional de Seguridad Integral and the Política de Defensa, the armed forces participated alongside the National Police in domestic law enforcement (Ministerio de Coordinación de Seguridad de Ecuador 2011). In 2011, for example, the military participated in 30,710 crime fighting operations including drug interdiction and arrests, such as Operativo Relámpago (Grupo de Trabajo en Seguridad Regional 2013, 5). In 2014, 52,355 such operations took place in El Oro, Guayas, and Imbabura, among other provinces (Cordero 2014).

In El Salvador, the military played a supporting role in patrols between the 1992 Peace Accords and 2002, but increased its involvement in domestic security afterwards (Aguilar 2016). Between 2003 to 2006, with Plans Mano Dura (2003) and Súper Mano Dura (2004), they became directly involved in seizures and arrests through joint police-military groups (Grupos de Tarea Antipandilla) and military-only units (Fuerzas de Tarea). Since 2009, the military has also conducted operations related to car theft prevention, arms smuggling, human trafficking, drug trafficking, protection of bus routes and school perimeters, and prison security. Between 2009 and 2014, more than ten specialized groups among the armed forces were created to combat organized crime. ${ }^{10}$ Today, an estimated $39 \%$ of El Salvador's armed forces participate in domestic law enforcement missions: 2,940 in citizen security; 2,575 in the prison system; and 580 in border security (Pérez 2015a).

Although the 1996 Peace Accords ending Guatemala's civil war led to the creation of the Civilian National Police (PNC), two years later the military began participating in joint operations with the PNC. Since the creation of the Joint Security Force (4,500 soldiers and 3,000 police) in 2000 , the military took the lead in the country's internal security, with the number and types of missions, number of troops, and areas patrolled increasing steadily. President Otto Pérez Molina (2012-2015) increased the number of domestic security missions assigned to the armed forcesover 116,000 in 2014 alone (Ministerio de la Defensa Nacional de Guatemala, 2014)_and created Fuerzas de Tarea and Special Reserve Corps for Citizen Security. Both forces are assigned to citizen-security tasks including patrolling, checkpoints, raids, highway security, and security patrols to prevent armed attacks on mass transit buses and public schools (Ministerio de la Defensa Nacional de Guatemala 2014). ${ }^{11}$

In Honduras, the armed forces have increasingly participated in domestic law enforcement since Ricardo Maduro's administration (2002-2006). During his presidency, the armed forces participated in joint operations with police in a small number of municipalities, such as 2003 Operación Libertad, in which 1,000 police and soldiers were ordered to patrol the streets of Tegucigalpa, or in 2004 when over 1,500 police and soldiers travelled aboard city buses to protect the drivers from extortion and violence. The military's involvement in internal security grew considerably during Porfirio Lobo's administration (2010-2014), with over 7,000 soldiers participating every year in public-safety operations throughout the country. Alongside the increase in operations, his government created the Military Police for Public Order in 2013, which is a security task force of nearly 5,000 armed forces with the mission of helping the National Police to maintain order (Poder Legislativo de Honduras 2013). Under president Juan Orlando Hernández (2014-present) the armed forces participate in an average of 300,000 domestic public safety missions each year (Secretaría de la Defensa Nacional de Honduras 2016).

Although the Mexican armed forces were involved sporadically in drug crop eradication missions throughout most of the twentieth century, by 1998 about 23,000 military personnel participated in anti-drug tasks on a daily basis (Mendoza 2016, 26). Continuing with this trend, president Vicente Fox's 2005 Operativo México Seguro involved 18,000 military personnel in drug eradication and capturing kingpins (Mendoza 2016). However, in December 2006 Felipe Calderón's (2006-2012) declaration of all-out war against drug traffickers marked the start of the military's protracted law enforcement operations in large parts of the territory to address not 
Table 1

Consequences of constabularization by country

\begin{tabular}{|c|c|c|c|c|}
\hline Country & Violence & Human Rights & Police Reform & Legal Framework \\
\hline & $\begin{array}{c}\text { Increase in violence } \\
\text { after } \\
\text { constabularization? }\end{array}$ & $\begin{array}{l}\text { Increase in HR abuses } \\
\text { after constabularization? }\end{array}$ & $\begin{array}{l}\text { Attempted and } \\
\text { completed police } \\
\text { reform? }\end{array}$ & $\begin{array}{c}\text { Gap between de jure and de } \\
\text { facto constabularization? }\end{array}$ \\
\hline Costa Rica & - & - & Completed & - \\
\hline Panama & - & 一 & $\begin{array}{c}\text { No attempt since } \\
1990\end{array}$ & 一 \\
\hline Argentina & - & 一 & No attempt* & - \\
\hline Chile & - & - & Completed & - \\
\hline Uruguay & - & - & Completed & - \\
\hline Bolivia & On trend & - & Unfinished & No \\
\hline Brazil & Decrease & $N / A$ & No attempt & For 10 years \\
\hline Paraguay & On trend & $\mathrm{N} / \mathrm{A}$ & No attempt & For 5 years \\
\hline Peru & Increase & $\mathrm{N} / \mathrm{A}$ & Unfinished & For 7 years \\
\hline Colombia & Bump & $\mathrm{N} / \mathrm{A}$ & Completed & No \\
\hline $\begin{array}{r}\text { Dominican } \\
\text { Republic }\end{array}$ & Increase & N/A & Unfinished & Yes \\
\hline Ecuador & Decrease & $\mathrm{N} / \mathrm{A}$ & Unfinished & For 4 years \\
\hline EI Salvador & Increase & $\mathrm{N} / \mathrm{A}$ & No attempt & Yes \\
\hline Guatemala & Increase & $\mathrm{N} / \mathrm{A}$ & Unfinished & No \\
\hline Honduras & Bump & $\mathrm{N} / \mathrm{A}$ & Completed & No \\
\hline Mexico & Increase & Increase & Unfinished & Yes*** \\
\hline Nicaragua & $N / A^{* *}$ & N/A & $\begin{array}{c}\text { No attempt since } \\
1996\end{array}$ & For 25 years \\
\hline Venezuela & On trend & $N / A$ & Completed & For 9 years \\
\hline
\end{tabular}

NB: Refer to the online appendix for sources and coding criteria.

*Argentina is conservatively coded as no attempt, but the main subnational police department, the Buenos Aires Police, completed successful reforms in the late 1990s.

**Nicaragua is coded as N/A because the available data begins after constabularization

${ }^{\star \star \star}$ In Mexico a 2019 National Guard law granted the president temporary power to deploy the armed forces for public security purposes under extraordinary situations until the National Guard is fully operational.

only drug trafficking but also organized crime more generally. Over 67,000 soldiers work permanently fighting criminal groups in at least twenty-four of the thirty-two Mexican states (Angel 2016).

The Nicaraguan military's law-enforcement tasks primarily take place in most of the countryside, patrolling highways, protecting the coffee harvest, and preventing cattle theft. Beginning in the 1990s, each year during the months of November to February, the military has participated in the Plan de Protección a la Cosecha Cafetalera, which includes joint army-police patrols of the coffee-growing fields. Since 2016, under the Plan Permanente de Seguridad en el Campo, the military maintains a permanent involvement in patrolling, checkpoints, highway security, operations of interdiction, confronting and arresting criminals. In that year, it participated in 92,416 missions in the departments of Boaco, Chontales, Jinotega, Matagalpa, and Rivas (Ejército de Nicaragua 2016).

In Venezuela, the 1999 Plan Nacional de Seguridad Ciudadana involved the armed forces in maintaining internal order and combating organized crime. President
Hugo Chávez (1999-2013) further increased the armed forces' involvement in law enforcement through Plan Confianza in 2001, Plan Seguridad Ciudadana Integral in 2003, and Plan Caracas Segura in 2008. In 2009 he created DIBISE (Dispositivo Bicentenario de Seguridad), which involved 1,200 National Guard personnel in flashy operations in crime-ridden neighborhoods. The plan also created public safety commands in each state, led by the National Guard. In 2013, president Nicolás Maduro repackaged DIBISE into Plan Patria Segura, which also tasked the armed forces with setting up security checkpoints and patrolling the streets (Donadio 2014). ${ }^{12}$

\section{Evaluating the Consequences of Militarization}

Having determined the extent to which the different types of militarized law enforcement are present, we evaluate whether the theoretical expectations play out in the region. As a first approximation, table 1 shows the extent to which there is cross-national evidence for the main consequences discussed in the theory section. Since different types of law enforcement co-exist in most 
countries, we emphasize the consequences of constabularization in the empirical analysis because its extreme nature helps uncover the effects of militarization. More generally, however, we expect the theorized consequences of militarization to become more prevalent in countries with higher degrees of militarization.

Recognizing the generalized lack of data and difficulty in establishing systematic indicators that work across contexts, as well as the fact that militaries are often called on to operate in more challenging environments to begin with-i.e., they are not randomly deployedthe criteria used for this initial evaluation are simple: whether constabularization preceded any increases, bumps, decreases, or no change in levels of violence and human rights complaints, whether police reform at the national level was attempted and completed (regardless of effectiveness), and whether constabularization has taken place outside of the prevailing legal order. Table 1 reflects this coding across countries with the exception of human rights violations, since most countries lack yearly data on human rights complaints against the military that can be evaluated systematically. The exception is Mexico, which is included in table 1. Although yearly data for human rights violations are not available for the crossnational evaluation, a regional discussion follows and further subnational evidence from Mexico is presented in the next section.

\section{Levels of Violence}

As table 1 suggests, temporary or sustained increased levels of violence followed in six of the nine countries that adopted generalized constabularization. Ecuador (decrease) and Venezuela (on trend) are cases in which constabularization did not precede sharp increases in the homicide rates, and in Nicaragua constabularization preceded the available data. Among the cases of limited constabularization, where the military operated in limited regions and periods of time, the evidence is mixed (with one increase, two on trend, and one decrease, out of four).

The trends in homicide rates shown in table 1 are supported by country-specific accounts regarding the consequences of militarization. Although the armed forces tend to be assigned to more difficult situations than other forms of law enforcement, making it difficult to assess whether they contribute to increased violence, the timing of militarization is consistent with surges in the adoption of tough-on-crime measures. In El Salvador, for example, spikes in homicide rates have followed constabularization under plans Mano Dura and Súper Mano Dura (García 2015). In Honduras, a temporary sharp increase in violent crime took place following constabularization with Operation Freedom in 2003, and another one followed by a surge in troop deployments in 2007. In Mexico, although many factors can contribute to increases in violence, systematic studies suggest constabularization is at least partly responsible for increased violence (FloresMacías 2018; Merino 2011; Osorio 2015).

\section{Human-Rights Violations}

Although human rights complaints filed against the armed forces are mostly absent from table 1 given the lack of standardized data for all but one Latin American country, available reports suggest that respect for human rights has deteriorated whenever more militarized forces have become involved in law enforcement. Across the region, constabularized militaries have been prone to conducting extra-judicial executions, crime scene manipulation, warrant-less searches, arbitrary arrests, and enforced disappearances.

Contrary to the view that militaries tend to be more professional than police departments and that their training makes them more respectful of civil liberties (den Heyer 2013; Wood 2015), reports of extra-judicial killings conducted by soldiers are widespread. Because of their greater disruptive capacity, soldiers' violations tend to be of greater magnitude-often leading to not only disappearances, torture, and arbitrary arrests, but even veritable massacres.

For example, in Venezuela, a human rights $\mathrm{NGO}$ (PROVEA), has documented over 700 extrajudicial killings during the Operaciones de Liberación y Protección del Pueblo (Unidad Investigativa sobre Venezuela 2016). In Honduras, there is evidence of military death squads with hit lists (Lakhani 2017). Reports also document extrajudicial killings in Colombia-with close to eight hundred soldiers convicted and sixteen generals investigated between 2002 and 2008 (Human Right Watch 2015)_and in Guatemala (Plaza Pública 2012). In Mexico, the military have been implicated in a number of massacres-including Tlatlaya in the state of Mexico (refer to the online appendix for Mexico's human-rights trends). In El Salvador, the Plan Mano Dura and Plan Súper Mano Dura resulted in the arbitrary arrests and disappearance of thousands of young adults believed to be part of gangs (Holland 2013). In Honduras, the National Human Rights Commission (CONADEH) has documented torture, kidnapping, and sexual violence perpetrated by the military (Human Rights Watch 2016).

Although systematic regional data is not available, country-specific reports suggest the armed forces have been responsible for widespread abuse wherever they operate. Given the high levels of impunity that characterize the region, and the generally opaque military tribunals that often have jurisdiction over soldiers' actions, holding the armed forces accountable for these violations remains an elusive task.

\section{Police Reform}

A reason governments cite for involving the armed forces is that doing so buys time in order to strengthen civilian 
law enforcement institutions: while the military provisionally address drug-trafficking, the government can (in theory, although rarely in practice) work on professionalizing the police and rooting out corruption (den Heyer 2013). This is the rationale behind Guatemala's gradual adoption of Plan of Operativización in 2017, Mexico's purge of municipal police forces, and Venezuela's creation of the new National Police and the Police University (UNES) between 2009 and 2013 (Hanson and Smilde 2013), for example.

Although there is variation in the extent of police reform, reforms have generally taken place among countries with no or partial constabularization. Conversely, with the exceptions of Colombia, Honduras, and Venezuela, countries with constabularized militaries have either struggled to carry out police reform or have not attempted reform in spite of needing it. For example, in Ecuador the involvement of the armed forces by decree contributed to the neglect of the 2004 police reform Plan Siglo XXI, which was much less visible than military patrols (Pontón 2007, 50). In Guatemala, recent efforts to reform the National Police have failed, in part due to lack of government funding toward the police given military priorities (Glebbeek 2009).

\section{Legal Incompatibility}

As table 1 shows, the constabularization of the armed forces has circumvented the prevailing legal order in most countries. In the Dominican Republic, Mexico, and El Salvador, militaries have conducted domestic law enforcement tasks either against legal restriction seeking to prevent this practice or without laws regulating it. In the Dominican Republic and El Salvador militaries' semipermanent involvement in domestic security contravenes constitutional restrictions requiring declared states of exception. In Mexico, the Supreme Court declared unconstitutional in 2018 the Interior Security Bill that sought to formalize the use of the military in public security.

Table 1 also shows several countries in which governments circumvented the legal order for years until legislation was modified. In Brazil (2004), Ecuador (2014), Nicaragua (2015), Peru (2010), Paraguay (2013), and Venezuela (2011), governments either modified the constitution or secondary legislation to legalize the intervention of the armed forces in domestic security. The legal disconnect brought about by constabularization has undermined the rule of law precisely by the same agency who was tasked with upholding it.

\section{Evidence from Mexico}

Whereas the previous section presented a region-wide evaluation, this section relies on sub-national evidence from Mexico to further assess the theoretical expectations. Mexico is useful to illustrate the consequences of militarization because of its generalized constabularization of the military since 2006, coexistence of myriad police forces that vary in their degree of militarization and span the spectrum found within Latin America, and fairly typical levels of violence for Latin America. Additionally, we can leverage a joint operation (Culiacán-Navolato) between the military and the federal police in Sinaloa state that began in 2008-for which we have information on confrontations and number of participating personnel (police and military) — to put our hypotheses to test.

First, regarding violence, systematic studies by FloresMacías (2018), Merino (2011), and Osorio (2015) suggest that Mexico's constabularization has resulted in greater violence compared to the police. As Lessing $(2013,2017)$ has shown, this policy has encouraged organized crime to respond in kind, including the formation of squadrons of hitmen with military-grade weapons, equipment, and tactics, especially in contexts of generalized corruption and impunity. This does not mean that violence would have remained at pre-constabularization levels in the absence of constabularization, since there are many causes behind the increase (Yashar 2018). Rather, as Flores-Macías (2018) shows using a synthetic control method to address endogeneity, the increase would have been less steep —a 17point difference in the homicide rate, on average.

We contribute additional evidence to these authors' findings by leveraging subnational evidence from a joint operation between the military and the federal police in Sinaloa state for which we obtained data through a series of freedom of information requests. To isolate the effect of militarization and account for the difficulty of the mission and context, we compare two municipalities that closely match in their homicide rates, socioeconomic characteristics, and presence of organized crime until the joint operation began in $2008 .{ }^{13}$ Though both municipalities experienced increases in violence after 2008, as seen in figure 4 , our controlled comparison suggests that the homicide rate per 100,000 people increased more in the municipality (El Fuerte) that was treated with military presence.

Providing additional evidence for militarization's greater disruptive capacity, Pérez Correa, Silva, and Gutiérrez (2015) show that, during encounters with suspected criminals in 2014, the ratio of civilians killed per soldier killed was fifty-three for the army and seventyfour for marines, compared to seventeen for federal police. That the armed forces' ratios are considerably higher than the ten to fifteen range suggests excessive use of violence (Chevigny 1991). Regarding the killed-to-wounded ratio, between 2007 and 2014 that of the federal police was 4.8 and the military's was 7.9. Moreover, according to the National Survey of Population Deprived of Liberty, 74\% of people detained by soldiers reported suffering some form of physical violence, almost 15 percentage points more than those detained by other civilian security forces (Ortega 2018). 


\section{Figure 4}

\section{Homicide rate in comparable municipalities with and without military presence}

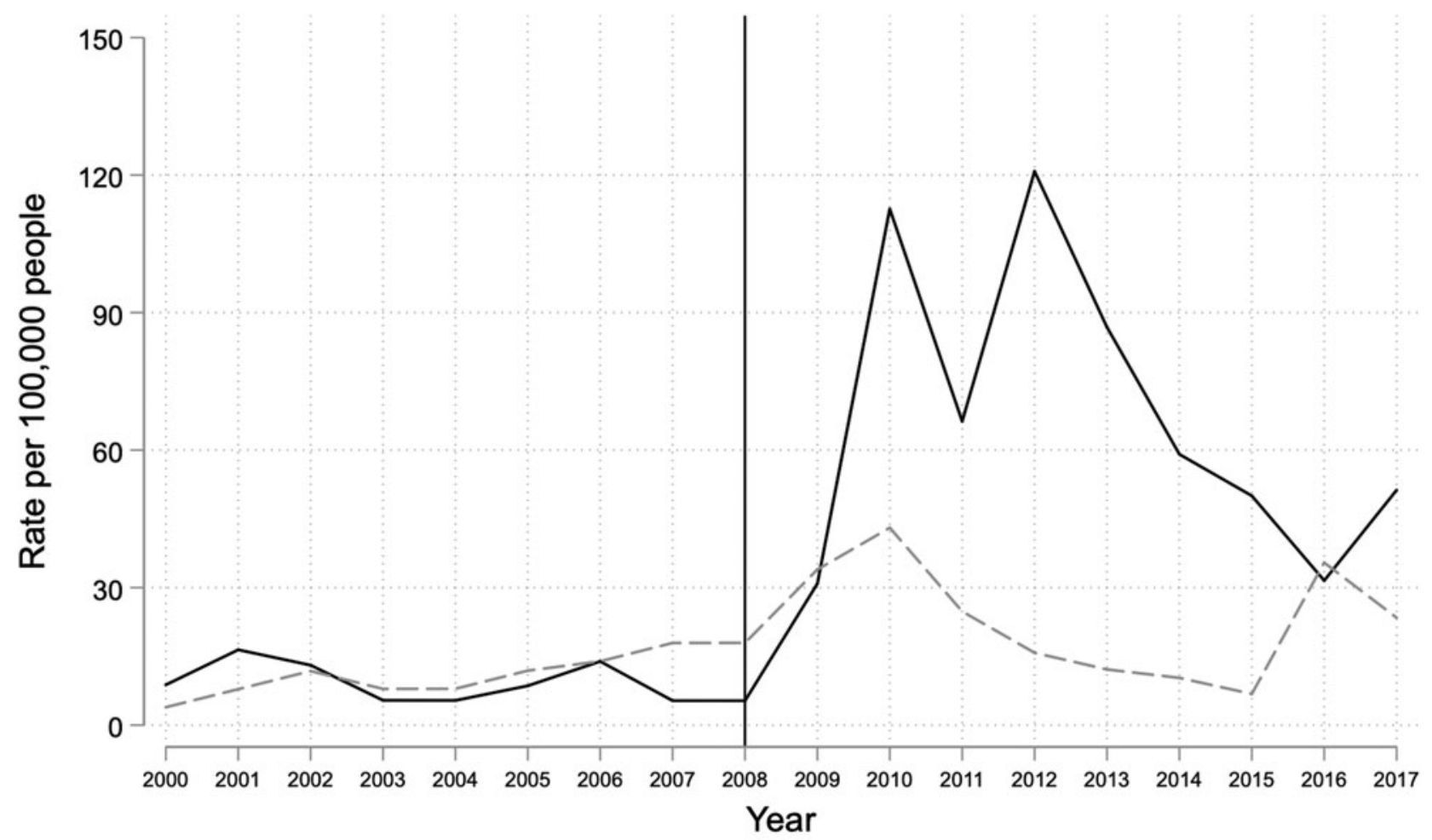

- El Fuerte, SIN - - Escuinapa, SIN

Note: The vertical black line indicates the start of the Culiacán-Navolato operation.

Second, regarding human rights, evidence from Mexico suggests that constabularized soldiers engage in more violations than police. According to Amnesty International (2016), the Mexican military routinely resort to torture, sexual violence, and other violations. Between 2007 and 2016, more than 13,100 cases of abuse against the armed forces were filed with the National Human Rights Commission (refer to the online appendix for details), more than twice the 5,423 filed against the federal police. A similar pattern holds if we look at rates: the rate of complaints against the military grew significantly once soldiers were deployed for public safety purposes - reaching forty-one complaints per 1,000 soldiers in 2011 compared to twenty-one for federal police.

To further test our hypothesis, we again leverage the joint operation between the military and the federal police in Sinaloa. The joint participation in the same operation helps address the concern that soldiers may typically be assigned to more difficult missions than police. Since the federal police does not provide information on officer deployment at the local level, we rely on data made available through press releases on the number of personnel participating in the joint operations that began in 2008. As shown in figure 5, on average, over twice as many complaints of human-rights abuses per 1,000 personnel were filed against soldiers compared to the federal police, even though both were deployed jointly.

Beyond differences in abuses between soldiers and federal police, we also leverage Mexico's federal system to compare abuse rates between other types of militarized security forces, namely the less militarized municipal police and the more militarized state police. While ideally one would have information on deployment and abuses for all state and municipal police forces in the country, we obtained data for two low-violence states Aguascalientes and Yucatán — and two high-violence states-Nuevo León and Coahuila. Examining both violent and non-violent contexts helps account for differences in difficulty of missions. ${ }^{14}$

Overall, we find that the more-militarized state police generate more abuse complaints than less-militarized municipal police, regardless of whether they operate in high or low violence contexts. Between 2010 and 2016, state police generated 3.2 more complaints per 1,000 police officers in Nuevo León and 2.7 more in Coahuila than their corresponding municipal police. ${ }^{15}$ Similarly, 


\section{Figure 5 \\ Rate of human rights complaints by security force in Sinaloa}

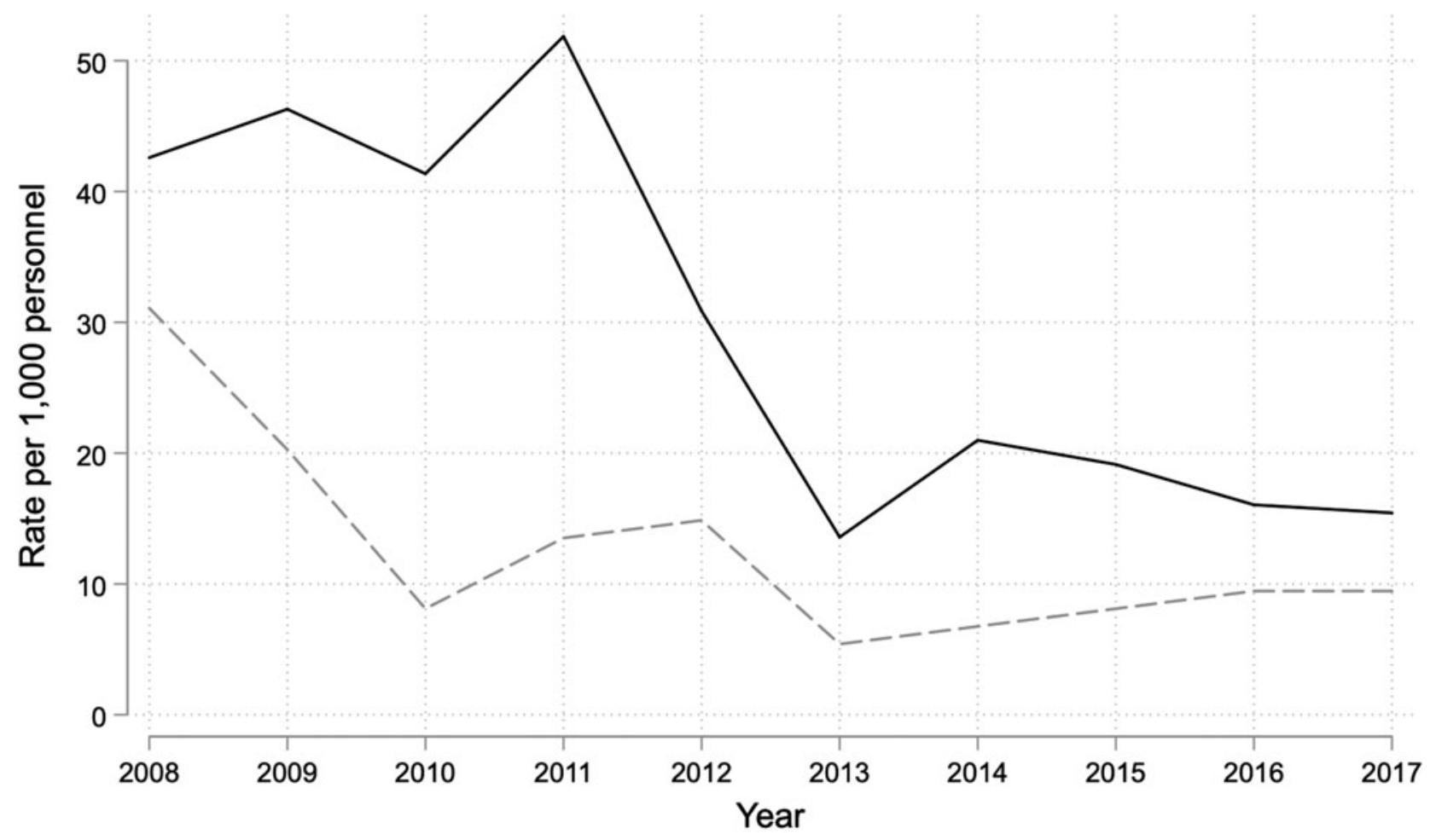

- Military (SEDENA) - - Federal Police

state police in Yucatán and Aguascalientes generated 1.7 more complaints than their municipal police.

Third, several attempts at reforming the federal police have failed since the constabularization of the military in 2006, in part because of the popularity and political expediency of constabularization compared to the difficulty, financial cost, and slow pace of professionalizing the police. Although the government has made some progress toward improving quality among police, constabularization has taken away the urgency of reform. Deadlines to adopt police certification systems have been postponed multiple times. Rather than deepening control mechanisms to address corruption and increase transparency and providing the necessary resources to professionalize the police, the federal government has relied on administrative reorganization, such as trying to unify police under a single chain of command (mando único) (Moloeznik and Suárez 2012) or dismantling the Ministry of Public Safety and folding its federal police under the Ministry of the Interior (Meyer 2014, 20).

The rollout of the National Gendarmerie in 2014 is a case in point. President Peña Nieto originally envisioned this force as complementing the federal police by adding between 40,000 and 50,000 paramilitary personnel and relieving the armed forces. Instead, due to the difficulty in recruiting and training police, the military remained on the streets and a small force of 5,000 members was incorporated into the existing federal police as its seventh division rather than the stand-alone gendarmerie that was planned (Meyer 2014, 20).

Further, while public safety expenditures have grown considerably over the last decade, governments have faced strong incentives to channel resources toward the constabularized armed forces. Between 2005 and 2019, governments increased the armed forces' budget by MX $\$ 69.6$ billion-three times the increase assigned to the federal police. Moreover, although as a candidate Andrés Manuel López Obrador promised to return the military to the barracks, once in office he expanded the army's budget by 15 percentage points and cut that of the federal police by 5.5 percentage points. ${ }^{16}$ In the end, the appeal of militarized solutions was such that a new paramilitary National Guard-two-thirds of whom will be soldiers-will entirely replace the federal police by January 2021. 
Fourth, Mexico's armed forces regularly conducted domestic law enforcement operations outside of the prevailing legal order and in clear violation of the Constitution, as confirmed by the Supreme Court's 2018 decision to overturn the Interior Security Bill aimed at regulating the use of the military for law enforcement purposes. This de facto state of emergency undermined legal certainty for both the armed forces and victims of abuses by the military.

The difficulty of prosecuting members of the armed forces has contributed to impunity and the lack of reparation toward victims. The 2011 murder of 29year-old Jorge Otilio by the military in Monterrey is illustrative. On his way to work, soldiers opened fire on his vehicle and wounded him. As he stepped out of his vehicle, soldiers fired six additional bullets to his head point blank. Unaware that security cameras were recording them, the soldiers misrepresented the facts in their report and tried to incriminate him by planting a weapon. When Otilio's family brought the case before a civilian court, the judge referred the case to a military tribunal instead. However, the tribunal claimed it had no jurisdiction because the soldiers were performing police duties. The case bounced back and forth between civilian and military jurisdictions for years because of the lack of legal clarity (Rea 2013). ${ }^{17}$

As Amnesty International has highlighted, this legal uncertainty has contributed to the generalized impunity the armed forces have enjoyed during domestic policing operations: "Despite the extraordinarily high number of complaints of sexual violence against women committed by the armed forces, the Army informed Amnesty International in writing that not one soldier had been suspended from service for rape or sexual violence from 2010 to 2015 " (2016). This is due to the military conducting parallel investigations that interfere with those of civilian prosecutors and because of the difficulty in getting soldiers to appear before civilian courts (Suárez-Enríquez 2017). Whereas the police also enjoy high levels of impunity in Mexico, the greater violence with which the armed forces operate make the consequences of impunity greater.

\section{Conclusion}

This research made several contributions to our understanding of militarization as Latin America's new law enforcement reality: we unpacked the concept and types of militarized law enforcement; developed theoretical expectations about its consequences for citizen security, police reform, the legal order, and the quality of democracy more generally; and evaluated them with evidence from Latin America and Mexico in particular. It showed that the separation between militaries and public safety that gained traction with the end of military dictatorships is being reversed. Because of rising crime, perceptions of military competence, and U.S. incentives, a majority of countries have engaged in the constabularization of the military, and nine have done so in a generalized fashion across the national territory-including countries with relatively low levels of violence, such as Ecuador and Nicaragua. Further, although the lack of systematic data makes cross-national comparisons challenging and the potential for endogeneity should be taken seriously, the findings suggest that increases in violence and human rights violations, unfinished police reform, and disconnect between the military's domestic operations and the legal order have tended to follow constabularization. Although further cross-national and country-specific research is required to improve our understanding of militarization's consequences in Latin America, by conceptualizing its different types, taking stock of its prevalence, and systematically generating and beginning to evaluate theoretical expectations, this article constitutes an important first step toward this end.

The prevalence of these outcomes in countries with constabularized militaries has important implications for Latin American democracies. High levels of violence undermine support for democracy (Arias and Goldstein $2010,2)$. They contribute to the notion that authoritarian forms of government might be preferable to address the country's problems. Across the region, 33\% of respondents consider that addressing rampant violence justifies a military coup, a worrisome share considering the region's low support for democracy and rising support for authoritarianism (Latinobarómetro 2015). In Guatemala, for example, people consider military governments to be more effective at controlling crime than democratic ones (Bateson 2010). Moreover, the sustained reliance on the armed forces can further erode confidence in civilian authorities and re-empower the military, which is ultimately damaging for democracy.

The military's human rights violations also undermine the quality of democracy, especially when accountability mechanisms are lacking. Whenever militaries operate outside of the legal framework, we can expect abuses to go unpunished. Compared to widespread police impunity typical in the region, not only is the magnitude of abuses greater because of the military's disruptive capacity, but the sense of impunity resulting from high stakes military operations also strengthens anti-democratic attitudes among the population. Moreover, building effective and trusted police agencies will likely be postponed as long as the armed forces remain involved in law enforcement. The implication of hindering police reform is that constabularization will perpetuate itself as a policy course at the expense of potentially better alternatives.

Constabularization has reversed progress made in civilmilitary relations regarding the de-militarization of public life since the region's democratization, which highlighted the importance of separating internal versus external coercion. Although military rule might seem part of 
a bygone era, reminders of the perils of military intervention are still present today. In Venezuela, the military participated in a failed coup in 2002, and in Honduras the armed forces ousted president Manuel Zelaya in 2009. These examples show how the armed forces continue to pose a threat to democracy in the region (Pion-Berlin and Martínez 2017, 4): democracy is far from consolidated and blurring the line between national defense and public safety opens the door to military rule.

In light of these considerations, and since there is little evidence that involving the military in law enforcement has reduced the levels of drug production, trafficking, or consumption (Kennedy, Reuter, and Riley 1993; Moreno-Sánchez, Kraybill, and Thompson 2003), governments would be well-advised to pay attention to, in addition to comprehensive judicial and police reform, long-term factors-including income inequality, education, and employment opportunities-that have been documented as causes behind the wave of criminal violence in the last two decades (Pérez 2015). Otherwise, moving soldiers out of the barracks and into the streets can further undermine the rule of law and increase levels of impunity - one of the primary reasons why people commit crimes (Kleiman 1993). This is the paradox of constabularizing the military in the region: while it remains a highly popular policy in Latin America, it appears to be ineffective at best and counterproductive at worst.

The phenomenon of using the military for law enforcement is extending to other parts of the worldespecially with the rise of democratically elected populist leaders-which makes the study of how civil-military relations affect democracies all the more pressing. In the Philippines, president Rodrigo Duterte has engaged the military in the country's anti-drug effort, and the levels of violence have skyrocketed (Moore 2017). In Indonesia, President Joko Widodo has directed the armed forces to participate in joint operations with the police (Jakarta Globe 2017). Although conditions are different regarding institutional constraints in these countries, the Latin American experience should inform efforts to militarize law enforcement elsewhere.

\section{Notes}

1 In which the armed forces take on the responsibilities of civilian law enforcement agencies.

2 For research on the different factors leading to violent crime in Latin America see Yashar 2018.

3 These factors can also contribute to the emergence of other forms of tough-on-crime policies, including harsher sentences.

4 The Posse Comitatus Act of 1878 limits the use of the military for domestic policy purposes.

5 We focus on human rights, citizen security, police reform, and the legal order because they are key features of good governance in liberal democracies; Mainwaring and Scully 2010.

6 General support (67\%) among Latin Americans for the military fighting crime is highest in El Salvador (85\%) and lowest in Uruguay (55\%); Americas Barometer by the Latin American Public Opinion Project (LAPOP) 2014.

7 President Macri announced in 2018 a new defense policy allowing the armed forces to combat twenty-first century threats like organized crime and terrorism. It is unclear what this will look like in practice once adopted.

8 These joint operations with the police are in addition to military activity aimed at defeating the Paraguayan People's Army; BBC Mundo 2016.

9 Brazil's state-level paramilitary police, Polícia Militar, are highly militarized. Although they follow a military command structure, they are not constabularized armed forces because they are not part of the national Defense Ministry; their primary function and training are the provision of public safety, not national security. We code Brazil as limited constabularization because its national army has been deployed to specific cities for limited periods of time. However, the theoretical expectation for the states' military police should hold insofar as they are more militarized than their civilian counterparts at the local level.

10 These include the Zeus Command, the Specialized Reaction Force and the Joint Community Support Groups; Santos 2015.

11 It remains to be seen if the gradual retreat of the army in citizen security tasks signed in December 2016 is implemented by 2019; Contreras 2017.

12 In addition to the constabularization of the armed forces, the Bolivarian National Police has also become more militarized. For example, Maduro created the Fuerzas de Acción Especial (FAES) in 2017.

13 Sinaloa has eighteen municipalities. Refer to the online appendix for a discussion on this comparison.

14 Data are for 2010-2016, the period covered by the Census of Municipal Governments.

15 State police in Mexico are primarily reactive forces with several militarized units created during the adoption of the Accredited State Police directive in 2011.

16 Based on the 2019 Budget Initiative.

17 This is in spite of a 2011 reform mandating that soldiers be tried in civilian courts for human-rights violations.

\section{Supplementary Materials}

I. Coding Criteria for the Consequences of Constabularization
A. Violence
B. Human Rights
C. Police Reform 


\section{Legal Order}

II. Supplemental Sources for the Section "Taking Stock of the Militarization of Law Enforcement," by Country

III. Sources for the Section "Evidence from Mexico"

To view supplementary material for this article, please visit https://doi.org/10.1017/S1537592719003906

\section{References}

Aguilar, Jeannette. 2016. "El rol del ejército en la seguridad interna en El Salvador." In Re-conceptualización de la violencia en el Triángulo Norte. El Salvador: Fundación Heinrich Böll-México.

American Civil Liberties Union. 2014. War Comes Home: The Excessive Militarization of American Policing. New York: ACLU.

Americas Barometer by the Latin American Public Opinion Project (LAPOP). 2014. www.LapopSurveys. org.

Amnesty International. 2016. "Mexico: Sexual Violence Routinely Used as Torture to Secure "Confessions" from Women." Amnesty International Online, June 28. 2017. "Brasil. Delitos contra la vida deben ser juzgados por tribunales ordinarios." Amnesty International Online, October 11.

Angel, Arturo. 2016. "Peña duplica el número de militares en las calles, aunque ninguna ley los regula." Animal Politico, October 6.

Arana, Daira and Miguel Ramírez. 2018. "La remilitarización de la seguridad pública en el Triángulo del Norte de Centroamérica y los esfuerzos internacionales para garantizar la protección de los derechos humanos en la región." Contextualizaciones Latinoamericanas 19: 1-15.

Arceneaux, Craig. 2001. Bounded Missions: Military Regimes and Democratization in the Southern Cone, University Park, PA: Penn State University Press.

Arias, Enrique Desmond and Daniel Goldstein. 2010. "Violent Pluralism: Understanding the New Democracies of Latin America." In Violent Democracies in Latin America, eds. Enrique Desmond Arias and Daniel Goldstein, 1-34. Durham, NC: Duke University Press.

Balko, Radley. 2013. The Rise of the Warrior Cop: The Militarization of America's Police Forces. New York: Public Affairs.

Bateson, Regina. 2010. "The Criminal Threat to Democratic Consolidation in Latin America." Presented at the Annual Meeting of the American Political Science Association, Washington, DC, September 2-5.

BBC Mundo. 2016. "¿Cuánto poder tiene el Ejército del Pueblo Paraguayo, la guerrilla que cometió la peor matanza de militares en los últimos años en Paraguay?” September 4.

Bickel, Karl. 2013. "Will the Growing Militarization of our Police Doom Community Policing?” Community
Policing Dispatch 6(12). https://cops.usdoj.gov/html/ dispatch/12-2013/will_the_growing_militarization_ of_our_police_doom_community_policing.asp

Bitencourt, Luis. 2007. "Crime and Violence: Challenges to Democracy in Brazil." In Citizenship in Latin America, eds. Joseph Tulchin and Meg Ruthenburg, 171-186. Boulder, CO: Lynne Rienner.

Chevigny, Paul. 1991. "Police Deadly Force as Social Control: Jamaica, Brazil, and Argentina." In Vigilantism and the State in Modern Latin America, ed. Martha Huggins, 189-218. New York: Praeger.

Contreras, Geovanni. 2017. "Plan de retiro de militares de las calles está en marcha." Prensa Libre, February 15 .

Cordero, Fernando. 2014. "Informe de Rendición de Cuentas 2014." Ministerio de Defensa de Ecuador.

Dammert, Lucía and John Bailey. 2005. "Reforma policial y participación militar en el combate a la delincuencia." Fuerzas Armadas y Sociedad 19(1): 133-52.

Delehanty, Casey, Jack Mewhirter, Welch Ryan, and Jason Wilks. 2017. "Militarization and Police Violence: The Case of the 1033 Program." Research and Politics 4(2): 1-7.

De Vedia, Mariano. 2016. "El Gobierno busca reforzar el plan antidrogas Escudo Norte." La Nación, January 4.

den Heyer, Garth. 2013. "Mayberry Revisited: A Review of the Influence of Police Paramilitary Units on Policing." Policing and Society 24(3): 346-61.

Donadio, Marcela. 2014. Atlas comparativo de la Defensa en América Latina. Buenos Aires: Red de Seguridad y Defensa de América Latina. (RESDAL)

- 2016. Atlas comparativo de la Defensa en América Latina. Buenos Aires: Red de Seguridad y Defensa de América Latina (RESDAL).

Dunlap, Charles. 1999. "The Police-ization of the Military." Journal of Political \& Military Sociology 27(Winter): 217-32.

Dunn, Timothy. 2001. "Border Militarization via Drug and Immigration Enforcement: Human Rights Implications." Social Justice 28(2): 7-30.

Economist, The. 2017. "The Brazilian Army Is Turning into a De Facto Police Force." July 6.

Ejército de Nicaragua. 2016. "Memoria Anual 2016." https://ejercito.mil.ni/contenido/relaciones-publicas/ publicaciones/docs/memoria-2016.pdf.

El Pais. 2016. "Una policía con acento militar." February 6.

El Peruano. 2016. "El estado de emergencia en el VRAEM regirá por 60 días." October 6.

Fitch, J. Samuel. 1998. The Armed Forces and Democracy in Latin America. Baltimore, MD: Johns Hopkins University Press.

Flores-Macías, Gustavo. 2018. "The Consequences of Militarizing Anti-Drug Efforts for State Capacity in Latin America: Evidence from Mexico," Comparative Politics 51(1): 1-20. 
Flores-Macías, Gustavo and Jessica Zarkin. 2019. "Explaining Public Support for Militarizing Law Enforcement: Evidence from a Conjoint Experiment in Mexico." Presented at the Annual Meeting of the American Political Science Association, Washington, DC, August 29-September 1.

Frühling, Hugo. 2003. "Police Reform and Democratization." In Crime and Violence in Latin America: Citizen Security, Democracy, and the State, eds. Hugo Frühling, Tulchin Joseph, and Heather Golding. Washington, DC: Woodrow Wilson Center Press.

García, Carlos. 2015. "Tracing the History of Failed Gang Policies in US, Northern Triangle." Insight Crime, December 3.

Glebbeek, Marie-Louise. 2009. "Post-War Violence and Police Reform in Guatemala." In Policing Insecurity. Police Reform, Security, and Human Rights in Latin America, ed. Niels Uildriks, 79-95. Lanham, MD: Lexington Books.

González, Eduardo. 2008. "Seguridad y policía en Costa Rica posterior a la Guerra Civil de 1948," Diálogos Revista Electrónica de Historia. Número especial: 1711-29.

González, Yanilda. 2017. "Why Police Reforms Rarely Succeed: Lessons from Latin America." The Conversation, July 16.

Grupo de Trabajo en Seguridad Regional. 2013. Los militares en la seguridad interna: retos y desafios para Ecuador. Quito: GTSR.

Hanson, Rebecca and David Smilde. 2013. "Citizen Security Reform Part II: The National Security University." Washington Office on Latin America (WOLA), February 6. https://venezuelablog.tumblr.com/post/ 42442603346/citizen-security-reform-part-2-thenational.

Hinton, Mercedes. 2006. The State on the Streets: Police and Politics in Argentina and Brazil. Boulder, CO: Lynne Rienner Publishers.

Holland, Alisha, 2013. "Right on Crime? Conservative Party Politics and Mano Dura Policies in El Salvador." Latin American Research Review 48(1): 44-67.

Human Rights Watch. 2015. "El rol de los altos mandos en falsos positivos." June 23.

—. 2016. "Honduras. Eventos 2016." World Report 2017. https://www.hrw.org/sites/default/files/world_ report_download/wr2017-web.pdf.

Hunter, Wendy. 1997. "Continuity or Change? Civil Military Relations in Democratic Argentina, Chile, and Peru." Political Science Quarterly 112(3): 453-75.

Huntington, Samuel. 1957. The Soldier and the State: The Theory and Politics of Civil-Military Relations. Cambridge, MA: Harvard University Press.

Isacson, Adam and Sarah Kinosian. 2017. "US Military Assistance and Latin America." WOLA Commentary, April 27. https://www.wola.org/analysis/u-s-militaryassistance-latin-america/.
Jakarta Globe, 2017. “Indonesia to Implement Duterte's Drug War Approach?” July 23.

Jaskoski, Maiah. 2013. Military Politics and Democracy in the Andes. Baltimore, MD: Johns Hopkins University Press.

Kennedy, Michael, Peter Reuter, and Kevin Jack Riley. 1993. "A simple economic model of cocaine production." Mathematical and Computer Modelling 17(2): 19-36.

Kleiman, Mark. 1993. "Enforcement Swamping: A Positive-feedback Mechanism in Rates of Illicit Activity." Mathematical and Computer Modelling 17(2): 65-75.

Kraska, Peter. 2007. "Militarization and Policing: Its Relevance to 21st Century Police.” Policing 1(4): 501-13. Lakhani, Nina. 2017. "Berta Caceres Court Papers Show Murder Suspects' Links to US-trained Elite Troop." The Guardian, February 28.

Latinobarómetro. 2015. Latinobarómetro 2015. Santiago: Corporación Latinobarómetro.

Lawson, Edward. 2018. "Police Militarization and the Use of Lethal Force." Political Research Quarterly 72(1): 177-89.

La Razón. 2016. "Gobierno peruano declara estado de excepción en 3 distritos por terrorismo." September 11.

Leal Buitrago, Francisco. 2004. "The Military and the National Security Doctrine." In Colombia From the Inside, 81. Amsterdam: Center for Latin American Research and Documentation.

Lessing, Benjamin. 2013. "The Logic of Violence in Drug Wars.” Stanford University, Freeman Spogli Institute for International Studies, Center for International Security and Cooperation. CISAC Working Paper 145. . 2017. Making Peace in Drug Wars: Crackdowns and Cartels in Latin America. New York: Cambridge University Press.

Llorente, María Victoria and Jeremy McDermott. 2014. “Colombia's Lessons for Mexico." In One Goal, Two Struggles: Confronting Crime and Violence in Mexico and Colombia, eds. Cynthia J. Arnson and L. Eric. Olson with Christine Zaino. Woodrow Wilson Center Reports for the Americas \#32. Washington, DC: Woodrow Wilson Center.

Mainwaring, Scott and Timothy Scully, eds. 2010. "Introduction." Democratic Governance in Latin America. Palo Alto, CA: Stanford University Press.

Marinho, Michelle and Dandara Tinoco. 2017. "A New Campaign Against Latin America's Epidemic of Homicide." Open Society Foundations, May 23.

McDermott, Jeremy. 2011. "Colombia's Criminal Bands Pose New Security Challenges.” BBC News, April 25.

Mendoza, Ana Paola. 2016. "Operaciones del ejército mexicano contra el tráfico de drogas: revisión y actualidad." Politica y Estrategia 128: 17-53.

Merino, José. 2011. "Los operativos conjuntos y la tasa de homicidios." Nexos, June 1. 
Meyer, Maureen. 2014. Mexico's Police: Many Reforms, Little Progress. Washington, DC: Washington Office on Latin America.

Ministerio de Coordinación de Seguridad de Ecuador. 2011. Plan Nacional de Seguridad Integral. Quito: Ministerio Coordinador de Seguridad.

Ministerio de Defensa de Bolivia. 2012. "Plan Ciudad Segura 2012.” Boletín Informativo 3(14).

Ministerio de la Defensa Nacional de Guatemala. 2014. Memoria de Labores 2014, Guatemala City: Latingraf Publicidad.

Moloeznik, Marcos Pablo and María Eugenia Suárez. 2012. "El Proceso de Militarización de la Seguridad Pública en México (2006-2010).” Frontera Norte 24(48): 121-44.

Moncada, Eduardo. 2009. "Toward Democratic Policing in Colombia? Institutional Accountability through Lateral Reform." Comparative Politics 41(4): 431-39.

Moore, Jack. 2017. "President Rodrigo Duterte Announces Plan to Draft Military into War on Drugs," Newsweek, February 2.

Moreno-Sánchez, Rocio, David Kraybill, and Stanley Thompson. 2003. "An Econometric Analysis of Coca Eradication Policy in Colombia." World Development 31(2): 375-83.

Mummolo, Jonathan. 2018. "Militarization Fails to Enhance Police Safety or Reduce Crime but May Harm Police Reputation." Proceedings of the National Academy of Sciences of the United States of America 115(37): 9181-9186.

Norden, Deborah. 1996. Military Rebellion in Argentina: Between Coups and Consolidation. Lincoln: University of Nebraska Press.

Noticias de América Latina y el Caribe. 2017. "Colombia: segundo informe sobre la implementación de los acuerdos con las Farc de la Fundación Paz y Reconciliación." July 21.

Ordorica, Ana Paula. 2011. "El Ejército y la ley." Nexos, December 1.

Ortega, Adriana. 2018. "Patrones de actuación en detenciones: ejército vs. autoridades civiles." Nexos, October 15.

Osorio, Javier. 2015. "The Contagion of Drug Violence." Journal of Conflict Resolution 59(8): 1403-32.

Paniagua, Solia. 2017. "Lanzarán a las calles más de 7000 agentes garantizar orden.” Hoy Digital, March 30.

Pereira, Anthony. 2005. Political (In)Justice: Authoritarianism and the Rule of Law in Brazil, Chile, and Argentina, Pittsburgh, PA: Pittsburgh University Press.

Pérez, David. 2015. "Les ponían contra la pared y les daban un balazo." El País, July 21.

Pérez, Orlando. 2015a. "Militarizing the Police Undermines Democratic Governance." Global Americans, August 3. 2015b. Civil-Military Relations in Post-conflict Societies: Transforming the Role of the Military in Central America. New York: Routledge.
Pérez Correa, Catalina, Carlos Silva, and Rodrigo Gutiérrez. 2015. "Índice de letalidad: menos enfrentamientos más opacidad." Nexos, July 1.

Perú21. 2017. "VRAEM seguirá en estado de emergencia por prórroga del Ministerio de Defensa." January 25.

Pion-Berlin, David. 2017. "A Tale of Two Missions: Mexican Military Police Patrols Versus High Value Targeted Operations." Armed Forces \& Society 43(1): 53-71.

Pion-Berlin, David and Rafael Martínez. 2017. Soldiers, Politicians, and Citizens: Reforming Civil-Military Relations in Latin America. New York: Cambridge University Press.

Pion-Berlin, David and Harold Trinkunas. 2010. "Civilian Praetorianism and Military Shirking During Constitutional Crises in Latin America." Comparative Politics 42(4): 395-411.

Plaza Pública. 2012. "Fiscalía guatemalteca inicia proceso contra militares por matanza campesinos." October 10.

Poder Legislativo de Honduras. 2013. Decreto No 1682013. Tegucigalpa, Honduras: La Gaceta.

Pontón, Daniel. 2007. "El proceso de reforma policial en Ecuador: Un tema relegado al olvido." Urvio. Revista Latinoamericana de Seguridad Ciudadana 2: 37-56.

Porfilio, Gabriel. 2015. "La Guardia Nacional Republicana del Uruguay y lo complejo de su existencia." Infodefensa.com, October 8.

Rea, Daniela. 2013. "Caso Otilio: dos años de impunidad castrense." Animal Politico, April 23.

Remmer, Karen. 1989. Military Rule in Latin America. New York: Unwin Hymen.

Rittinger, Eric and Matthew Cleary. 2013. "Confronting Coup Risk in the Latin American Left." Studies in Comparative International Development 48(4): 40331.

Santos, Jessel. 2015. "El Salvador tiene 4 policías por cada 1,000 habitantes." La Prensa Gráfica, September 11.

Sartori, Giovanni. 1970. "Concept Misformation in Comparative Politics." American Political Science Review 64(4): 1033-53.

Schultze-Kraft, Markus. 2012. "La cuestión militar en Colombia: la fuerza pública y los retos de la construcción de la paz." In Construcción de paz en Colombia, ed. Angelika Rettberg. Bogotá: Universidad de los Andes.

Secretaría de Defensa Nacional de Honduras. 2013. "Memoria 2013 Secretaría de Defensa Nacional." http://www.dip.mindef.mil.gt/memoria_labores_20122013.pdf.

2016. "Informe de logros de la Secretaría de Defensa Nacional.

Security Assistance Monitor. 2017. Security Aid_Dashboard, Washington, DC. 
Stepan, Alfred. 1988. Rethinking Military Politics: Brazil and the Southern Cone. Princeton, NJ: Princeton University Press.

Suárez-Enriquez, Ximena. Justicia Olvidada. La Impunidad de las Violaciones a Derechos Humanos Cometidas por Soldados en México. Washington Office on Latin America (WOLA), November. https://www.wola.org/wp-content/ uploads/2017/11/WOLA_MILITARY-CRIMES_ RPT_SPANISH.pdf.

Telam. 2017. "Crearán un centro de comando para la lucha contra el narcotráfico." May 1.

Tilly, Charles. 1992. Coercion, Capital, and European States, AD 990-1992. Cambridge, MA: Blackwell.

Trujillo Álvarez, Pedro. 2018. "Proceso de Militarización de la Seguridad Pública en América Latina. El Triangulo Norte Centroamericano," Contextualizaciones Latinoamericanas 19: 1-18.

Ungar, Mark. 2011. Policing Democracy: Overcoming Obstacles to Citizen Security in Latin America. Washington, DC: Woodrow Wilson Center Press.

Unidad Investigativa sobre Venezuela. 2016. "Ejecuciones extrajudiciales acompañan a redadas de seguridad en Venezuela." Insight Crime, September 13.

U.S. Department of State. 2015. International Narcotics Control Strategy Report (Paraguay). Washington, DC. https://2009-2017.state.gov/j/inl/rls/nrcrpt/2015/ vol1/239004.htm.
Weeks, Gregory. 2006. "Fighting Terrorism while Promoting Democracy: Competing Priorities in US Defense Policy toward Latin America." Journal of Third World Studies 23(2): 59-77.

Willits, Dale and Jeffrey Nowacki. 2014. "Police Organization and Deadly Force: An Examination of Variation across Large and Small Cities." Police \& Society 24(1): 63-80.

Wood, Nathan. 2015. "The Ferguson Consensus Is Wrong: What Counterinsurgency in Iraq and Afghanistan Teaches Us about Police Militarization and Community Policing." Lawfare Research Paper Series 3(1): 1-22.

Yashar, Deborah. 2018. Homicidal Ecologies: Illicit Economies and Complicit States in Latin America. New York: Cambridge University Press.

Youngers, Coletta. 2000. "Cocaine Madness: Counternarcotics and Militarization in the Andes." NACLA Report on the Americas 34(3): 16-23.

. 2004. "The Collateral Damage of the US War on Drugs: Conclusions and Recommendations." In Drugs and Democracy in Latin America: The Impact of US Policy, eds. Coletta Youngers and Eileen Rosin. Boulder, CO: Lynne Rienner.

Zaverucha, Jorge. 2008. "La militarización de la seguridad pública en Brasil." Nueva Sociedad 213: 128-46. 